Check for updates

Cite this: RSC Adv., 2018, 8, 3343

Received 19th December 2017 Accepted 10th January 2018

DOI: $10.1039 / \mathrm{c} 7 \mathrm{ra13479g}$

rsc.li/rsc-advances

\section{A solid-phase approach for the synthesis of $\alpha$-aminoboronic acid peptides $\uparrow$}

\author{
Blake E. Daniels and Craig E. Stivala (iD * \\ A solid-phase synthesis of $\alpha$-aminoboronic acid peptides using a 1-glycerol polystyrene resin is described. \\ Standard Fmoc solid-phase peptide chemistry is carried out to construct bortezomib and ixazomib. This \\ approach eliminates the need for liquid-liquid extractions, silica gel column chromatography, and HPLC \\ purifications, as products are isolated in high purity after direct cleavage from the resin.
}

$\alpha$-Aminoboronic acids are currently being investigated for their utility as reversible covalent inhibitors in a diverse range of therapeutic applications (Fig. 1). ${ }^{\mathbf{1}}$ These compounds' Lewis acidity enables the formation of stable tetrahedral adducts with nucleophilic residues in biological targets (Fig. 2). In 2003, the first boronic acid drug, bortezomib, was approved for the treatment of multiple myeloma. ${ }^{2}$ Ixazomib, a related $\alpha$-aminoboronic acid inhibitor, was later approved in 2015 for the same indication. ${ }^{3}$

Peptidic $\alpha$-aminoboronic acids, such as bortezomib and ixazomib, have traditionally been assembled using standard peptide coupling techniques, ${ }^{4}$ wherein an $\alpha$-aminoboronic ester is introduced onto a pre-constructed peptide and is subsequently deprotected to unmask the boronic acid. Metalcatalyzed decarboxylative borylation strategies have also been

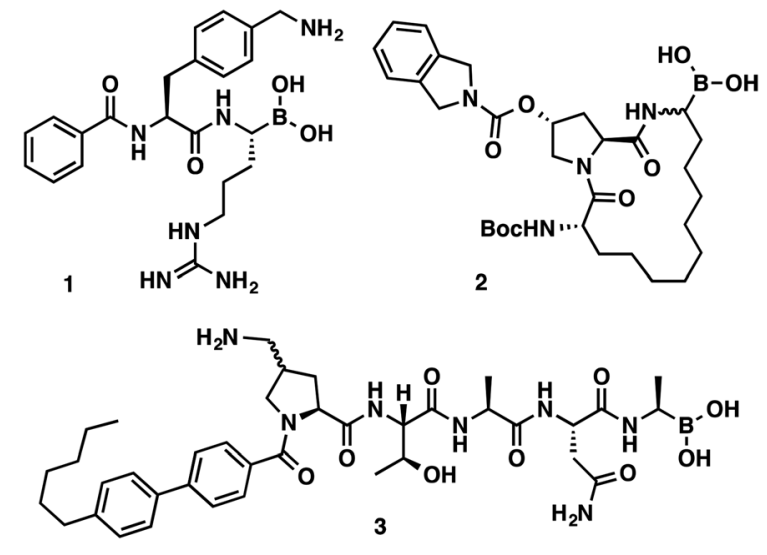

Fig. $1 \alpha$-Aminoboronic acids featured in various drug discovery programs. Flaviviral protease inhibitor (1), HCV protease inhibitor (2), LepB inhibitor (3).

Discovery Chemistry, Genentech, Inc., 1 DNA Way, South San Francisco, CA 94080, USA. E-mail: stivala.craig@gene.com

$\dagger$ Electronic supplementary information (ESI) available. See DOI: 10.1039/c7ra13479g reported for the preparation of $\alpha$-aminoboronic acid peptides. ${ }^{5}$ This approach provides direct access to these compounds from their parent peptide constructs but sacrifices stereochemical integrity.

Regardless of the method, $\alpha$-aminoboronic acid/ester peptides are difficult to prepare for a number of reasons. ${ }^{6}$ First, the $\mathrm{C}-\mathrm{B}$ bond can be oxidatively labile. ${ }^{7}$ Second, $\alpha$-aminoboronic acids and esters containing an unsubstituted $\alpha$ amino group can undergo a spontaneous 1,3-rearrangement (Scheme 1, A); this process can be minimized or suppressed entirely if the amino group is rapidly acylated or protonated. ${ }^{\mathbf{8}}$ Third, boronic esters can be hydrolytically labile, especially at low pH (Scheme 1, B). ${ }^{6,9}$ Therefore, any multistep approach must entail careful extractive workups and purifications to ensure that the ester remains intact.

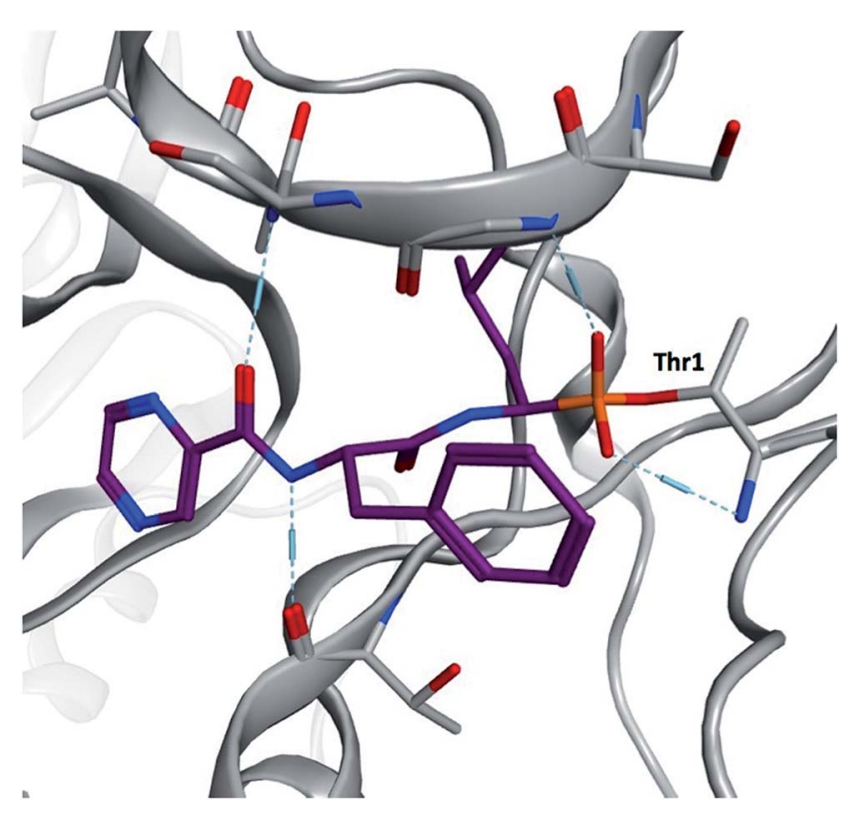

Fig. 2 Yeast 20S proteasome in complex with bortezomib (PDB ID 2F16). The boronic acid forms a stable tetrahedral adduct with the $\mathrm{N}$ terminal threonine (Thr1). 


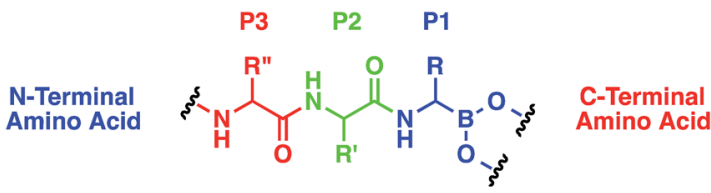

A. $\mathrm{C}$ to $\mathrm{N}$ migration of free $\alpha$-aminoboronic acids

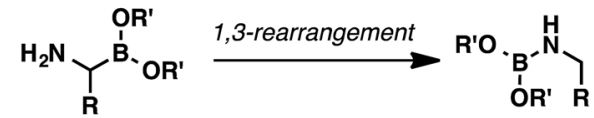

B. Relative Thermodynamic Stabilities of Boronic Esters ${ }^{9}$<smiles>[R]B1OCC(P)O1</smiles>

Scheme 1 General considerations for preparing $\alpha$-aminoboronic acid peptides.

While solid-phase peptide synthesis (SPPS) has become a standard method for the construction of peptides, ${ }^{10}$ this technology has remained underexplored for the preparation of $\alpha$-aminoboronic acid peptides. ${ }^{11}$ An approach of this type could eliminate liquid-liquid extractions and HPLC purifications and could enable high-throughput access to this class of compounds. To the best of our knowledge, there has only been one report of C-terminal SPPS to generate $\alpha$-aminoboronic acid peptides (Scheme 2). ${ }^{12}$ Although this study provides a critical conceptual foundation, the approach it describes lacks the simplicity of a traditional solid-phase approach, requiring a complex 8-step synthesis to prepare resin-bound $\alpha$-aminoboronic ester 6 for SPPS. This limitation may preclude its use as a general strategy for the preparation of $\alpha$-aminoboronic acid peptides.

We sought to identify an approach that could enable access to resin-bound $\alpha$-aminoboronic acids for SPPS in a limited number of steps using the emerging supply of commercially available $\alpha$-aminoboronic acid building blocks. The Klein group recently described the use of a 1-glycerol polystyrene resin that could be used for Fmoc SPPS to construct boronic acid-containing peptides. ${ }^{13-15}$ These results prompted us to explore the use of this resin for preparation of $\alpha$-aminoboronic acid peptides, specifically bortezomib and ixazomib.

Considering the unique reactivity of $\alpha$-aminoboronic acids, we needed to devise a concise loading strategy that would suppress the potential for $\mathrm{C}$ to $\mathrm{N}$ boron migration. This required

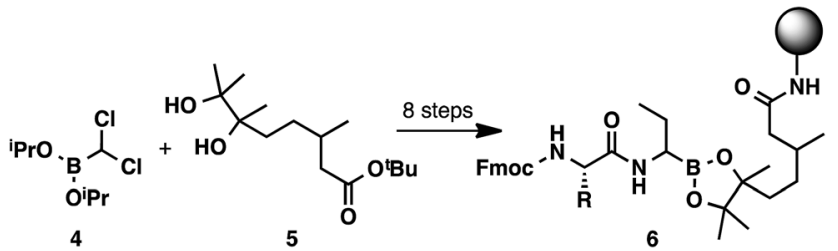

Scheme 2 8-Step preparation of a resin-bound $\alpha$-aminoboronic acid for C-terminal SPPS.

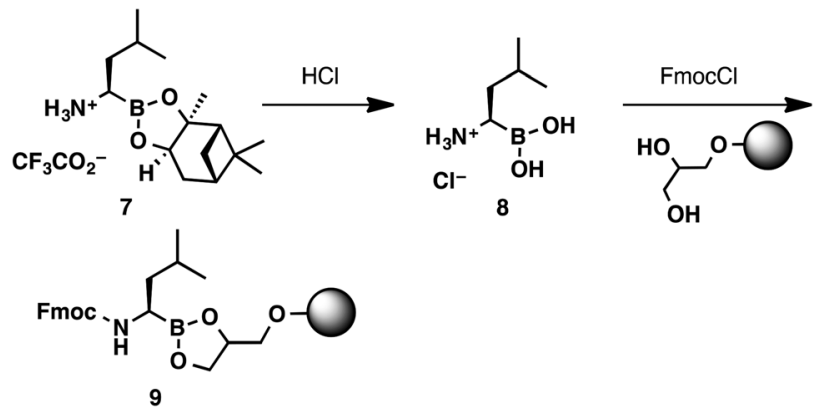

Scheme 3 2-Step protocol for loading boroleucine onto a 1-glycerol polystyrene resin.

the amine to remain protonated or acylated throughout the loading process. These considerations lead to the design of a two-step loading protocol (Scheme 3). Commercially available boroleucine pinanediol ester 7 was hydrolysed with aqueous $\mathrm{HCl}$. The boroleucine salt (8) was isolated in quantitative yield, free of pinanediol impurities, after a simple liquid-liquid extraction. The crude boroleucine salt was then shaken with the 1-glycerol polystyrene resin (loading capacity $0.6 \mathrm{mmol} \mathrm{g}^{-1}$ ), ${ }^{13}$ Fmoc chloride, and $N, N$-diisopropylethylamine to provide resinbound Fmoc-protected boroleucine 9.

With the C-terminal $\alpha$-aminoboronic acid resin in hand, we used standard Fmoc SPPS coupling techniques ${ }^{16}$ to synthesize bortezomib (Scheme 4). Fmoc deprotection (piperidine, DMF) and amide coupling (Fmoc-Phe-OH, TBTU, $N, N$-diisopropylethylamine, DMF) delivered intermediate 10. A subsequent Fmoc deprotection/coupling sequence with pyrazinecarboxylic acid produced resin-bound bortezomib 11. Hydrolysis of the resin bound peptide was accomplished with gentle shaking in a THF/ water mixture. ${ }^{13}$ Filtration and concentration delivered bortezomib (7-steps from boroleucine pinanediol ester 7) in 54\% yield and in $>95 \%$ purity.
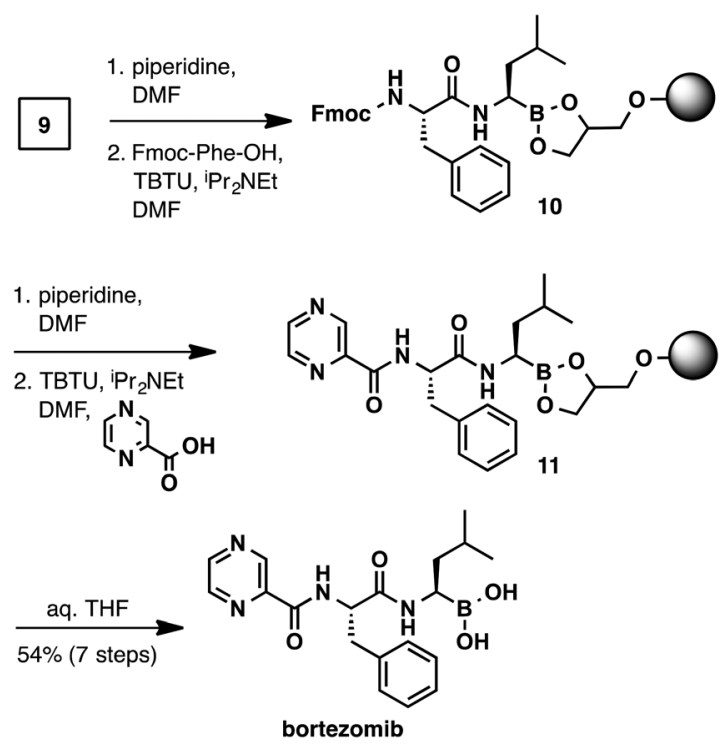

Scheme 4 Solid-phase synthesis of bortezomib. 

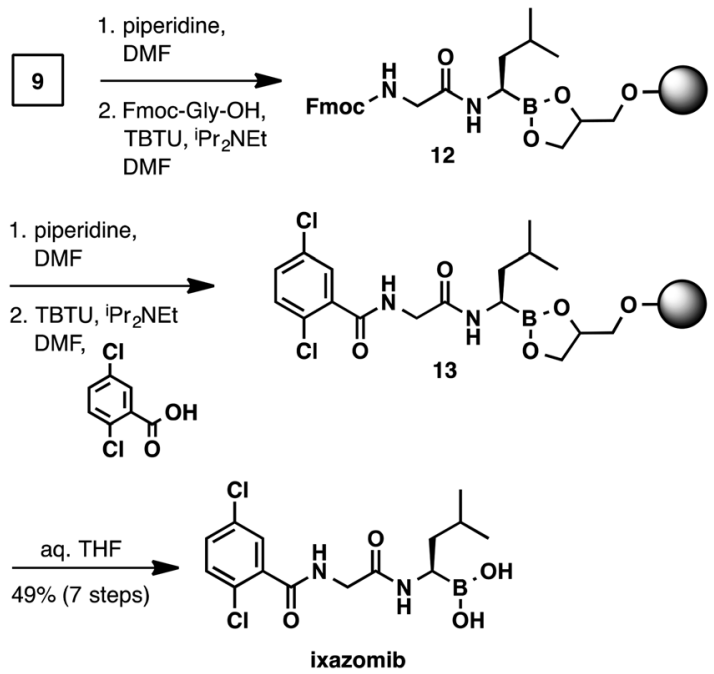

Scheme 5 Solid-phase synthesis of ixazomib.

The synthesis of ixazomib (Scheme 5) was accomplished in an analogous manner. Fmoc deprotection (piperidine, DMF) and amide coupling (Fmoc-Gly-OH, TBTU, $N, N$-diisopropylethylamine, DMF) delivered intermediate 12. The deprotection/ coupling sequence was repeated with 2,5-dichlorobenzoic acid to generate resin-bound ixazomib 13. Finally, boronic ester hydrolysis (THF/water) provided ixazomib in $49 \%$ yield and in $>95 \%$ purity.

\section{Conclusions}

This proof-of-concept study details the use of the 1-glycerol polystyrene resin for C-terminal SPPS of $\alpha$-aminoboronic acid peptides. The $\alpha$-aminoboronic acid used in this study was loaded onto the resin in 2 steps from a commercially available building block. This loading protocol represents a dramatic improvement to what has been reported previously. While the efficiency of the solid-phase synthesis of bortezomib (7 steps from $7,54 \%$ yield) and ixazomib (7 steps from $7,49 \%$ yield) is comparable to other standard synthetic approaches, ${ }^{4,5}$ the use of a solid support enables $\alpha$-aminoboronic acid peptides to be constructed rapidly in high purity and eliminates the need for workup and purification.

\section{Experimental procedures}

\section{General}

All commercial reagents and anhydrous solvents were used without additional purification. Boroleucine pinanediol ester 7 was purchased from Ark Pharm (Cat. \# AK-44948, CAS \# 17932487-9). 1-Glycerol polystyrene resin was purchased from Iris Biotech (Cat. \# BR-5206.0025). Nuclear magnetic resonance (NMR) spectra were acquired on a Bruker Avance DPX400 operating at 400 and $100 \mathrm{MHz}$ for ${ }^{1} \mathrm{H}$ and ${ }^{13} \mathrm{C}$, respectively, and are referenced internally according to residual solvent signals. NMR data were processed using MNova software and recorded as follows: ${ }^{1} \mathrm{H}-\mathrm{NMR}$ - chemical shift $(\delta, \mathrm{ppm})$, multiplicity (s, singlet; d, doublet; t, triplet; q, quartet; m, multiplet), coupling constant $(\mathrm{Hz})$, and integration; ${ }^{13} \mathrm{C}-\mathrm{NMR}$ - chemical shift $(\delta$, ppm). High-resolution mass spectra (HRMS) were recorded on a Thermo Scientific Orbitrap Q Exact mass spectrometer. Reactions were monitored by a Shimadzu LCMS/UV system with LC-30AD solvent pump, 2020 MS, Sil-30AC auto sampler, SPDM30A UV detector, CTO-20A column oven, using a $2-98 \%$ acetonitrile $/ 0.1 \%$ formic acid (or $0.001 \%$ ammonia) gradient over 2.5 minutes. Purity was determined by LCMS analysis with an Agilent 1290 UHPLC coupled with Agilent MSD (6140) mass spectrometer using ESI as ionization source. The LC separation used a Phenomenex XB-C18, $1.7 \mu \mathrm{m}, 50 \times 2.1 \mathrm{~mm}$ column with a $0.4 \mathrm{~mL} \mathrm{~min}^{-1}$ flow rate. Solvent $\mathrm{A}$ was water with $0.1 \% \mathrm{FA}$ and solvent $\mathrm{B}$ was acetonitrile with $0.1 \% \mathrm{FA}$. The gradient consisted of $2-98 \%$ solvent B over $7 \mathrm{~min}$ and hold $98 \%$ B for $1.5 \mathrm{~min}$ following equilibration for $1.5 \mathrm{~min}$. The LC column temperature was $40{ }^{\circ} \mathrm{C}$. UV absorbance was collected at $220 \mathrm{~nm}$ and $254 \mathrm{~nm}$.

Synthesis of boronic acid 8. $(R)$-Boroleucine-( $1 S, 2 S, 3 R, 5 S)$ $(+)-2,3$-pinanediol ester trifluoroacetate $(1.00 \mathrm{~g}, 2.64 \mathrm{mmol}, 1.00$ equiv.) and isobutylboronic acid (297 $\mathrm{mg}, 2.77 \mathrm{mmol}, 1.05$ equiv.) were suspended in heptane $(5.86 \mathrm{~mL}, 0.45 \mathrm{M})$. Hydrochloric acid $(5.86 \mathrm{~mL}, 0.45 \mathrm{M})$ was added, and the reaction mixture was stirred at room temperature for two hours. Upon consumption of the starting material, the reaction mixture was diluted with water and heptane (both $10 \mathrm{~mL}$ ). The aqueous layer was separated and concentrated under reduced pressure to afford $(R)$-boroleucine hydrochloride $8(442 \mathrm{mg}$, quantitative yield) as a white solid. ${ }^{1} \mathrm{H}$ NMR $\left(400 \mathrm{MHz}\right.$, methanol- $\left.\mathrm{d}_{4}\right) \delta 2.84$ (br s, 1H), 1.78-1.64 (m, 1H), $1.53(\mathrm{~m}, 2 \mathrm{H}), 0.97(\mathrm{~d}, J=6.6 \mathrm{~Hz}$, $3 \mathrm{H}), 0.96(\mathrm{~d}, J=6.4 \mathrm{~Hz}, 3 \mathrm{H})$. HRMS (ESI) calcd for $\mathrm{C}_{5} \mathrm{H}_{15} \mathrm{O}_{2} \mathrm{NB}$ $[\mathrm{M}+\mathrm{H}]^{+}:$132.1190, found 132.1188 .

\section{General procedure for solid-phase synthesis of $\alpha$ - aminoboronic acids}

Step 1. Resin loading - 1-glycerol polystyrene resin (loading capacity $0.6 \mathrm{mmol} \mathrm{g}^{-1}, 1.50 \mathrm{~g}, 20 \mathrm{mmol}$ ) was swollen in $\mathrm{CH}_{2} \mathrm{Cl}_{2}$ for 30 minutes and then dried via vacuum filtration. Fmoc chloride (556 mg, $2.15 \mathrm{mmol}, 3.6$ equiv.), (R)-boroleucine hydrochloride (100 mg, $0.597 \mathrm{mmol}, 1.0$ equiv.), THF $(10 \mathrm{~mL}$, $0.06 \mathrm{M})$, and then $N, N$-diisopropylethylamine $(0.38 \mathrm{~mL}$, 2.15 mmol, 3.6 equiv.) were added to the resin and the reaction mixture was shaken overnight. The resin was dried by vacuum filtration and washed sequentially with THF, $\mathrm{CH}_{2} \mathrm{Cl}_{2}$, and DMF $(3 \times 10 \mathrm{~mL}$ each). Note - Quantitative loading of the $\alpha$-aminoboronic acid is assumed.

Step 2. Fmoc deprotection - piperidine (10\% in DMF, $20 \mathrm{~mL}$, $21.8 \mathrm{mmol}$ ) was added to the resin and the suspension was shaken for 20 minutes. The resin was dried by vacuum filtration and washed with DMF $(2 \times 10 \mathrm{~mL})$. This procedure was repeated to ensure complete deprotection.

Step 3. Peptide coupling - N,N-diisopropylethylamine $(0.42$ $\mathrm{mL}, 2.39 \mathrm{mmol}, 4.0$ equiv.), an Fmoc-amino acid (1.79 mmol, 3.0 equiv.), and TBTU (587 mg, $1.79 \mathrm{mmol}, 3.0$ equiv.) were added to the resin in $\mathrm{CH}_{2} \mathrm{Cl}_{2}(10 \mathrm{~mL})$ and DMF $(10 \mathrm{~mL})$. The reaction mixture was shaken for two hours. The resin was dried 
by vacuum filtration and washed with DMF $(2 \times 10 \mathrm{~mL})$ and $\mathrm{CH}_{2} \mathrm{Cl}_{2}(2 \times 10 \mathrm{~mL})$.

Step 4. Cleavage from resin - the resin was dried by vacuum filtration, washed with $\mathrm{DMF}, \mathrm{CH}_{2} \mathrm{Cl}_{2}$, and $\mathrm{Et}_{2} \mathrm{O}(3 \times 10 \mathrm{~mL}$ for each), and dried under vacuum. The dried resin was treated with $9: 1 \mathrm{THF} /$ water $(40 \mathrm{~mL})$ and stirred overnight at room temperature. The resin was filtered and the filtrate concentrated under vacuum to afford the pure $\alpha$-aminoboronic acid.

Bortezomib. Bortezomib - recovered as a white solid in $54 \%$ yield (124 mg). ${ }^{1} \mathrm{H}$ NMR (400 MHz, methanol-d $\left.{ }_{4}\right) \delta$ 9.13-9.06 (m, $1 \mathrm{H})$, 8.77-8.68 (m, 1H), 8.65-8.58 (m, 1H), 7.36-7.14 (m, 5H), 4.84-4.67 (m, 1H), 3.23-3.14 (m, 1H), 3.12-3.01 (m, 1H), 2.97$2.87(\mathrm{~m}, 1 \mathrm{H}), 1.47-1.28(\mathrm{~m}, 3 \mathrm{H}), 1.28-1.17(\mathrm{~m}, 1 \mathrm{H}), 0.82-0.73$ $(\mathrm{m}, 6 \mathrm{H})$. HRMS (ESI) calcd for $\mathrm{C}_{19} \mathrm{H}_{24} \mathrm{O}_{3} \mathrm{~N}_{4} \mathrm{~B}[\mathrm{M}-\mathrm{OH}]^{+}$: 367.1936, found 367.1925.

Ixazomib. Ixazomib - recovered as a white solid in $49 \%$ yield (106 mg). ${ }^{1} \mathrm{H}$ NMR $\left(400 \mathrm{MHz}\right.$, methanol-d $\left.{ }_{4}\right) \delta 7.60\left(\mathrm{dd}, J_{1}=J_{2}=\right.$ $1.5 \mathrm{~Hz}, 1 \mathrm{H}), 7.49-7.46(\mathrm{~m}, 2 \mathrm{H}), 4.23(\mathrm{~s}, 2 \mathrm{H}), 2.83-2.75(\mathrm{~m}, 1 \mathrm{H})$, 1.74-1.61 (m, 1H), 1.42-1.32 (m, 2H), 0.97-0.90 (m, 6H). HRMS (ESI) calcd for $\mathrm{C}_{14} \mathrm{H}_{18} \mathrm{O}_{3} \mathrm{~N}_{2} \mathrm{BCl}_{2}[\mathrm{M}-\mathrm{OH}]^{+}$: 343.0782, found 343.0770.

\section{Conflicts of interest}

There are no conflicts to declare.

\section{Acknowledgements}

The authors would like to thank Baiwei Lin and Kewei Xu for obtaining analytical data.

\section{References}

1 For reviews see: $(a)$ B. A. Teicher and J. E. Tomaszewski, Biochem. Pharmacol., 2015, 96, 1-9; (b) P. Andrés, G. Ballano, M. I. Calaza and C. Cativiela, Chem. Soc. Rev., 2016, 45, 2291-2307; (c) R. Smoum, A. Rubinstein, V. M. Dembitsky and M. Srebnik, Chem. Rev., 2012, 112, 4156-4220; (d) S. Touchet, F. Carreaux, B. Carboni, A. Bouillon and J.-L. Boucher, Chem. Soc. Rev., 2011, 40, 3895; (e) M. a Soriano-Ursúa, B. C. Das and J. G. TrujilloFerrara, Expert Opin. Ther. Pat., 2014, 24, 485-500; $(f)$ P. C. Trippier and C. McGuigan, MedChemComm, 2010, 1, 183; $(g)$ V. M. Dembitsky, A. A. A. Quntar and M. Srebnik, Mini-Rev. Med. Chem., 2004, 4, 1001-1018. For representative examples of $\alpha$-aminoboronic acids being developed for various therapeutic applications see: $(h)$ S. M. Drawz, M. Babic, C. R. Bethel, M. Taracila, A. M. Distler, C. Ori, E. Caselli, F. Prati and R. A. Bonomo, Biochemistry, 2010, 49, 329-340; (i) M. De Rosa, L. Lu, E. Zamaratski, N. Szałaj, S. Cao, H. Wadensten, L. Lenhammar, J. Gising, A. K. Roos, D. L. Huseby, R. Larsson, P. E. Andrén, D. Hughes, P. Brandt, S. L. Mowbray and A. Karlén, Bioorg. Med. Chem., 2017, 25, 897-911; (j) T. Tran, C. Quan, C. Y. Edosada, M. Mayeda, C. Wiesmann, D. Sutherlin and B. B. Wolf, Bioorg. Med. Chem. Lett., 2007, 17, 1438-1442; (k) A. Boloor, D. Hanway,
M. Joshi, D. T. Winn, G. Mendez, M. Walls, P. Wei, F. Qian, X. Zhang, Y. Zhang, M. E. Hepperle, X. Li, D. A. Campbell and J. M. Betancort, Bioorg. Med. Chem. Lett., 2009, 19, 5708-5711; (l) T. Akopian, O. Kandror, C. Tsu, J. H. Lai, W. Wu, Y. Liu, P. Zhao, A. Park, L. Wolf, L. R. Dick, E. J. Rubin, W. Bachovchin and A. L. Goldberg, J. Biol. Chem., 2015, 290, 11008-11020; (m) L. J. Milo, J. H. Lai, W. Wu, Y. Liu, H. Maw, Y. Li, Z. Jin, Y. Shu, S. E. Poplawski, Y. Wu, D. G. Sanford, J. L. Sudmeier and W. W. Bachovchin, J. Med. Chem., 2011, 54, 4365-4377; (n) D. T. Vogl, T. G. Martin, R. Vij, P. Hari, J. R. Mikhael, D. Siegel, K. L. Wu, M. Delforge and C. Gasparetto, Leuk. Lymphoma, 2017, 58, 1872-1879; (o) D. A. Bachovchin, L. W. Koblan, W. Wu, Y. Liu, Y. Li, P. Zhao, I. Woznica, Y. Shu, J. H. Lai, S. E. Poplawski, C. P. Kiritsy, S. E. Healey, M. DiMare, D. G. Sanford, R. S. Munford, W. W. Bachovchin and T. R. Golub, Nat. Chem. Biol., 2014, 10, 656-663; (p) J. Lei, G. Hansen, C. Nitsche, C. D. Klein, L. Zhang and R. Hilgenfeld, Science, 2016, 353, 503-505; (q) S. E. Poplawski, J. H. Lai, Y. Li, Z. Jin, Y. Liu, W. Wu, Y. Wu, Y. Zhou, J. L. Sudmeier, D. G. Sanford and W. W. Bachovchin, J. Med. Chem., 2013, 56, 3467-3477.

2 (a) A. Paramore and S. Frantz, Nat. Rev. Drug Discovery, 2003, 2, 611-612; (b) J. Adams, M. Behnke, S. Chen, A. A. Cruickshank, L. R. Dick, L. Grenier, J. M. Klunder, Y.-T. Ma, L. Plamondon and R. L. Stein, Bioorg. Med. Chem. Lett., 1998, 8, 333-338; (c) J. Adams and M. Kauffman, Cancer Invest., 2004, 22, 304-311.

3 Z. T. Al-Salama, K. P. Garnock-Jones and L. J. Scott, Target Oncol., 2017, 12, 535-542; P. Moreau, T. Masszi, N. Grzasko, N. J. Bahlis, M. Hansson, L. Pour, I. Sandhu, P. Ganly, B. W. Baker, S. R. Jackson, A.-M. Stoppa, D. R. Simpson, P. Gimsing, A. Palumbo, L. Garderet, M. Cavo, S. Kumar, C. Touzeau, F. K. Buadi, J. P. Laubach, D. T. Berg, J. Lin, A. Di Bacco, A.-M. Hui, H. van de Velde and P. G. Richardson, N. Engl. J. Med., 2016, 374, 1621-1634. 4 (a) M. A. Beenen, C. An and J. A. Ellman, J. Am. Chem. Soc., 2008, 130, 6910-6911; (b) R. C. Roemmele and M. A. Christie, Org. Process Res. Dev., 2013, 17, 422-426.

5 C. Li, J. Wang, L. M. Barton, S. Yu, M. Tian, D. S. Peters, M. Kumar, A. W. Yu, K. A. Johnson, A. K. Chatterjee, M. Yan and P. S. Baran, Science, 2017, 356(6342), eaam7355. 6 D. G. Hall, Boronic Acids, Wiley-VCH Verlag GmbH \& Co. KGaA, 2006, p. 1.

7 D. S. Matteson, J. Organomet. Chem., 1999, 581, 51-65. 8 C. Laplante and D. G. Hall, Org. Lett., 2001, 3, 1487-1490. 9 (a) C. D. Roy and H. C. Brown, J. Organomet. Chem., 2007, 692, 784-790; (b) G. Springsteen and B. Wang, Tetrahedron, 2002, 58, 5291-5300.

10 (a) F. Guillier, D. Orain and M. Bradley, Chem. Rev., 2000, 100, 3859; P. Blaney, R. Grigg and V. Sridharan, Chem. Rev., 2002, 102, 2607-2624. (b) P. Hodge, Chem. Soc. Rev., 1997, 26, 417; (c) P. Hodge, Ind. Eng. Chem. Res., 2005, 44, 8542-8553.

11 For an N-terminal SPPS synthesis of $\alpha$-aminoboronic acids see: S. Elgendy, G. Patel, D. Green, C. A. Goodwin, 
M. F. Scully, W. Husman, E. Skordalakes, V. V. Kakkar and J. J. Deadman, Tetrahedron Lett., 1997, 38, 3305-3308.

12 R. M. Dunsdon, J. R. Greening, P. S. Jones, S. Jordan and F. X. Wilson, Bioorg. Med. Chem. Lett., 2000, 10, 1577-1579.

13 M. A. M. Behnam, T. R. Sundermann and C. D. Klein, Org. Lett., 2016, 18, 2016-2019.

14 R. B. Merrifield, J. Am. Chem. Soc., 1963, 85, 2149-2154.

15 For boronic acid solid supports see: (a) D. G. Hall, J. Tailor and M. Gravel, Angew. Chem., Int. Ed., 1999, 38, 3064-3067; (b) C. Pourbaix, F. Carreaux, B. Carboni and H. Deleuze, Chem. Commun., 2000, 1275-1276; (c) M. Gravel, K. A. Thompson, M. Zak, C. Bérubé and D. G. Hall, J. Org. Chem., 2002, 67, 3-15; (d) B. Carboni, C. Pourbaix, F. Carreaux, H. Deleuze and B. Maillard, Tetrahedron Lett., 1999, 40, 7979-7983.

16 N. Zinieris, L. Leondiadis and N. Ferderigos, J. Comb. Chem., 2005, 7, 4-6. 